\title{
Immunomodulatory Trace Element (Zinc) In HIV Sero Positive Individuals
}

\author{
Ibiene Sarah Kalio ${ }^{1}$; Oroma G. Eddeh-Adjugah ${ }^{2}$ \\ ${ }^{I}$ School of Medical Laboratory Science, Rivers State College of Health Science and Technology, Rumueme, \\ PMB 5047, Port Harcourt Rivers State, Nigeria \\ ${ }^{2}$ Rivers State Primary Health Care Management Board, Rivers State, Nigeria.
}

\begin{abstract}
This study was carried out to determine immunomodulatory trace element zinc in HIV positive individuals. Serum zinc, albumin and total protein in twenty five HIV positive individuals were compared with twenty four HIV negative individuals (control).Methods: Atomic absorption spectrophotometer (AAS) method was adopted to determine concentration of zinc. Bromocresol green method and Biuret method were used respectively to determine albumin and total Protein respectively.Result:The mean $\pm S D$ for zinc is $0.2 \pm 0.13 \mathrm{mg} /$, Albumin 33.18 $\pm 12.61 \mathrm{~g} / \mathrm{l}$ and total Protein $31.35 \pm 9.05 \mathrm{~g} / \mathrm{l}$ in HIV positive individuals while in the control the values are zinc $1.36 \pm 1.11 \mathrm{mg} / \mathrm{l}$, Albumin $39.68 \pm 13.20 \mathrm{~g} / \mathrm{l}$ and total protein $61.22 \pm 26.85 \mathrm{~g} / \mathrm{l}$ respectively. All three parameters were significantly low in HIV positive individuals than in HIV negative individuals. Zinc $(P<0.05)$, Albumin $(P<0.05)$ and total Protein $(P<0.05)$. These changes were attributed to nutritional factors and destruction of cells in intestine by the immune system.
\end{abstract}

Keynote: Zinc, immunomodulatory, trace elements, immune modulator, HIV and carrier proteins

\section{Introduction:}

Immunomodulatory trace elements are those trace elements which have the ability to regulate immune functions, such as zinc, copper, selenium iron and magnesium. Trace elements are inorganic micronutrients essential for normal health and by definition make up less than 0.01 percent of the body's dry weight (Crook, 2006). Zinc also known as spelter is a metallic chemical element with symbol $\mathrm{Zn}$ and atomic number 30. It is a component of more than 200 mammalian metallo-enzymes (Prasad, 1993) and is widely distributed in food (oatmeal, green onion, corn meal) mainly bound to proteins (Burtis, 2008). It's bioavailability is dependent on digestion of these proteins to allow zinc bind to peptides, amino acids and other ligands within the intestinal tract (Burtis, 2008). Excessive absorption of zinc suppresses iron absorption (Forsmire, 1990) while deficiency is due to insufficient dietary intake leading to growth retardation, delay wound healing, decrease sense of smell and diverse skin lesions (Ibs et al., 2003). Mild zinc deficiency depresses immunity (Ibs et al., 2003). Albumin a carrier protein binds and transports zinc (Burtis, 2008). About $80 \%$ of plasma zinc is associated with albumin and most of the rest bound in the high molecular proteins gamma macroglobin (Burtis, 2008).

HIV causes depression in immunity by primarily affecting T cell which is responsible for the body's ability to defend itself against foreign organisms (Liang et al., 1996). In HIV infection, zinc plays specific roles as an antioxidant, immune modulator (Tanaka, 1990) and a possible direct anti-viral agent (Favier, 1994). Although zinc plasma pool is small, it is highly mobile and immunologically very important (Miller, 1989). Zinc in-vitro has been found to inhibit cell death mediated by tumor necrosis factor, a cytokine linked to cellular apoptosis and wasting syndrome in HIV (Fleiger et et al., 1989). Zinc is necessary for normal function of the immune system (Rink et al., 2000). The functions of innate immunity are disturbed by altered zinc levels (Chakavis et al., 1999). Zinc is required by human beings and pathogens for proliferation. Thus a decreasing plasma zinc levels during acute phase infection is a defense mechanism of human organisms (Clohessy et al., 1995). Beta cell which represents main cells of humoral Immunity and T-cells are reduced during zinc deficiency (Moulder, 1989). In HIV replication, viral RNA is transformed into viral DNA via the enzyme reverse transcriptase, and then the enzyme integrase allows for the integration of viral DNA with host DNA (South et al., 1990).

Zinc binds to the integrase enzyme via structures and allows for optimal activity of the integrase enzyme (South et al., 1990). The incident of zinc deficiency in HIV infection has been documented in multiple studies (Flavier et al., 1992). In a survey of 228 in patients with AIDS, 29 percent had low serum zinc and $21 \%$ had marginally low serum zinc levels (Koch et al., 1996). The presence of zinc deficiency in these patients significantly increased the chance of bacterial infection (Koch et al., 1996). Deficiency of zinc in AIDS patients occur as a result of malabsorption, medication, altered metabolic states, fluid loss from nausea, vomiting and diarrhea (Gelb et al., 1986). Zinc deficiency in both plasma and serum has been observed in HIV positive patients in the asymptomatic state as well. Marginally low plasma zinc levels were found in 50\% of 100 healthy asymptomatic HIV-1 Seropositive patients without history of alcoholism or clinical evidence of nutritional 
deficiencies (Beach et al., 1992). Although the net effects of in-vivo tissue zinc concentration on HIV replication is yet to be determined. There is evidence that adding zinc to antiviral medication enhances the medication effect by acting as an immunomodulator (Prasad, 2003).

This study aims to determine the level of serum zinc in HIV individuals and to compare them with HIV negative individuals.

\section{Materials And Methods}

Twenty five HIV positive individuals attending the outpatient clinic of University of Port Harcourt Teaching Hospital, Rivers State of South South Nigeria were used as test subjects while twenty four HIV negative individuals from the immediate community served as control. Exclusion criteria included pregnant women, children, individuals suffering from diabetes, kidney problems and tuberculosis to avoid their influence on zinc level.

Five millimeters of blood samples were collected from the participants to obtain serum samples. Samples were screened for HIV antibodies using ELISA test innotest HIV/HIV2 by innogenetics (Belgium). Zinc was determined in samples using the Uniscope AA $320 \mathrm{~N}$ atomic absorption spectrophotometer.

Biuret method and Bromocresol green method were used to determine total protein and albumin respectively.

\section{Results}

The result showing the concentration of immunomodulatory trace element in twenty five HIV positive individual and twenty four HIV negative individual is summarized in the table one below:

Table 1: Result of concentration of immunomodulatory trace element (zinc) with statistical evaluation $(n=25)$ for HIV positive and $(n=24)$ for control.

\begin{tabular}{|l|l|l|l|}
\hline Parameter & $\begin{array}{l}\text { HIV (Positive Individuals) } \\
\text { Mean } \pm \text { SD }\end{array}$ & $\begin{array}{l}\text { Control } \\
\text { Mean } \pm \text { SD }\end{array}$ & P Value \\
\hline Zinc $(\mathrm{mg} / \mathrm{l})$ & O.20 \pm 0.13 & $1.36 \pm 1.11$ & $<0.05$ \\
\hline Albumin (g/l) & $33.18 \pm 12.61$ & $39.68 \pm 13.20$ & $<0.05$ \\
\hline Total Protein (g/l) & $31.35 \pm 9.05$ & $61.22 \pm 26.85$ & $<0.05$ \\
\hline
\end{tabular}

The result of this study showed significance difference in the mean zinc $(\mathrm{mg} / \mathrm{l})$ concentration of $0.20 \pm$ 0.13 in HIV positive individuals and $1.36 \pm 1.11$ in HIV negative individuals $(\mathrm{P}<0.05)$. Also there was significance difference in Albumin ( $\mathrm{g} / \mathrm{l}$ ) concentration of $33.18 \pm 12.61$ in HIV positive individuals and $39.68 \pm 13.20$ in HIV negative individuals $\mathrm{P}<0.05$. There was significant difference in total protein $(\mathrm{g} / \mathrm{l})$ $31.35 \pm 9.05$ in HIV positive individuals and $61.22 \pm 26.85$ in HIV negative individuals $(\mathrm{P}<0.05)$. All three parameters were significantly lower in HIV negative individuals than HIV positive individuals.

\section{Discussion}

In this study, serum zinc concentration was significantly reduced in HIV positive individuals than HIV negative individuals which collaborates the works of Baum et al., (2000) when they examined zinc content in HIV patients (Ballester et al., 1986), in congenital diseases such as sickle cell anemia and in down syndrome (Licastro et al., 1992). Low zinc concentration is likely due to redistribution of zinc from plasma to other tissues and can also be attributed to a reduction in the hepatic production of the zinc carrier protein $\alpha_{2}-$ macroglobulin and to a rise in metallothionein, a protein that transports zinc to the liver. The reduced zinc concentration is consistent with the report of Shenbagarathai et al., (2008) when they documented marginally low levels of zinc in HIV patients attending Government Rajaji Hospital in Madurai India. He attributed the low levels to nutritional factors, enteropy and acute phase reactant proteins. Low plasma zinc levels, either congenital or acquired, are associated with immune abnormalities, impaired healing processes and increased susceptibility to infections (Baum et al., 2000).

The importance of zinc status in HIV infected patients has not been fully understood. According to Lee et al., (1997), zinc enhances multimerization and enzymatic activity of viral integrase. Also it has been found that zinc is a component of HIV-1 nucleocapsid proteins (Darlix et al., 1995; Berthoux et al., 1997). Zinc is used for gene expression, multimerization and integration in HIV-1 since it is a zinc-dependent virus and this may explain the low plasma zinc levels often observed in HIV-1 infected patients (Moccheggiani et al., 1995).

Albumin concentration was significantly reduced in HIV positive individuals in this study, which is in agreement with the observation of Graham et al., (2007) in women infected with HIV.Although albumin levels are not a marker of HIV infection status, they have been found to be a strong predictor of mortality in HIVpositive adults and children (Olawuni, 2006).Albumin like immunomodulatory trace element zinc is necessary for normal function of the immune system (Rink et al., 2000). A reduction could be attributed to increased demand for immunomodulatory trace element zinc in an immune deficient state like HIV. 
Total protein was also significantly reduced in HIV positive individuals which were similar to the work of Ugwuja and Eze, (2006). Decrease in serum total protein in HIV infection has been associated with either increased losses and/or catabolism or as a result of reduction in intake and/or absorption due to sores in the mouth, pharynx and/or esophagus, fatigue, depression and side effects of medications (Macallan, 1999).Increased demand for zinc in an immunodeficient state like HIV could lead to more active incorporation of zinc into metallo-enzymes and plasma proteins in the liver. About $80 \%$ of plasma zinc is associated with albumin and most of the rest bound in high molecular proteins gamma macroglobin (Burtis et al., 2008).

Reduction in Zinc parameter is consistent with the work of Koch et al., (1999) who documented incidence of zinc deficiency in HIV/AIDS patients and noted that zinc deficiency significantly increased the chance of bacterial infection.

In conclusion, immunomodulatory trace element zinc was greatly reduced in an immunodeficient state, thus implying that HIV/AIDS patients may be greatly deficient in immune fighting minerals in their system. It is suggested that further study be carried out to make a comparative study of zinc concentration in different stages of immunodeficiency.

\section{References}

[1]. Ballester, O. F., Abdallah, M. \& Prasad, A. S. (1986) Lymphocyte subpopulation abnormalities in sickle cell anemia: a distinctive pattern from that of AIDS. Am. J. Haematol. 21:23-27.

[2]. Baum, M. K., Shor-Posner, G. and Campa, A.(2000).Zinc Status In Human Immunodeficiency Virus Infection. The American Society for Nutritional Science. 9pp.

[3]. Beach, R., Mantero-Atienza, E. and Shor-Posner, G. (1992).specific nutrient abnormalities in asymptomatic HIV-I infection, AIDS; 6: 701-708.

[4]. Berthoux, L., Pechoux, C., Ottman, M., Morel, G. \& Darlix, J. L. (1997) Mutations in the N-terminal domain of human immunodeficiency virus type 1 nucleocapsid protein affect virion core structure and proviral DNA synthesis. J. Virol.71:6973-6981.

[5]. Burtis, C. A. (2008.) fundamentals of clinical chemistry. Pp 376-379.

[6]. Chakavis, T., May, A. E. and Kanse, S. M. (1999). Molecular mechanism of zinc-dependent leukocyte adhesion involving the urokinase receptor and P 2-integrins Blood, 93: 2976-2983:

[7]. Clohessy, P. A. and Golden, B. E. (1995).Protection - mediated zinc chelation as a biostatic mechanism in host defence, Scand, J, immunol.42: 551-556.

[8]. Crook, M. A. Clinical chemistry and metabolic medicine $7^{\text {th }}$ Edition.Edward Arnold Publisher.Pp 120-125.

[9]. Darlix, J. L., Lapadat-Tapolsky, M., de Rocquigny, H. \& Roques, B. P. (1995) First glimpses at structure-function relationships of the nuclecapsid protein of retroviruses.J. Mol. Biol. 254:523-537.

[10]. Favier, A. O. M. (1992). The role of zinc in acquired immunodeficiency syndrome, J.Intern.med; 231:463-469.

[11]. Fleiger, D.,Reithnoller, G. Z. and Heitbrock, H. W. L. (1989). $\mathrm{Zn}^{2+}$ inhibits both tumor necrosis factor - mediated DNA fragmentation and cytolysis.Int. J. Cancer; 44:315-319.

[12]. Fosmire, G.J. (1990). Zinc toxicity. American Journal of Clinical Nutrition,51:225.

[13]. Gelb A. and Miller, S. (1986). AIDS and gastroenterology Am. J. Gastroenterology, 81:619-622.

[14]. Graham S. M., Baeten, J. M., Richardson, B. A., Wener, M. H., Lavreys. L., Mandaliya, K., Ndinya-Achola, J. O., Overbaugh, J.,McClelland, R. S. (2007) A decrease in albumin in early HIV type 1 infection predicts subsequent disease progression.AIDS Res Hum Retroviruses. 23(10):1197-200.

[15]. Ibs, K. H. and Rink, L, (2003). Zinc - altered immune function. Journal of Nutrition, 133

[16]. Koch J, Neal E, et al (1996), Zinc levels and infection in hospitalized patients with AIDS Nutrition; 12:575-518.

[17]. Lee, P.S.,Xiao,J.,Knutson,J.R.,Lewis,m.s,\& Han,M.K(1997) $\mathrm{Zn}^{2+}$ promotes the self association of human immunodeficiency virus type-1 integrase in vitro.Biochemistry $36: 173-180$

[18]. Liang B, S Chung, M Araghniniknam LC lane and RR Watson (1996) vitamins and immunomodulation in AIDS nutrition, 12 (1):17.

[19]. Licastro, F., Mocchegiani, E., Zannotti, M., Arena, G., Masi, M. \& Fabris, N. (1992) Zinc affects the metabolism of thyroid hormones in children with Down's syndrome: normalization of thyroid stimulating hormone and of reversal triiodothryonineplasmic levels by dietary zinc supplementation. Int. J. Neurosci. 65:259-268.

[20]. Macallan, D. C. (1999).Wasting in HIV infection and AIDS. J. Nutr. 129: 238S-242

[21]. Miller S (1989). AIDS and gastroenterology Am J Gastroenterology, 81:619-622.

[22]. Mocchegiani, E., Veccia, S., Ancarani, F., Scalise, G. \& Fabris, N. (1995) Benefit of oral zinc supplementation as an adjunct to zidovudine (AZT) therapy against opportunistic infections in AIDS. Int. J. Immunopharmacol. 17:719-727.

[23]. Moulder, K. and Steward, M.W. (1989). Experimental zinc deficiency: effects on cellular responses and affinity of hundred antibody clinic, Exp, Immune 77:269-274 (medicine)

[24]. Olawuni, H. O. (2006). The value of serum albumin in pretreatment assessment and monitoring of therapy in HIV/AIDS patients.HIV Med 7: $351-355$.

[25]. Prasad A.S (2003). Zinc deficiency. British medical journal,326:409.

[26]. Prasad A. S.(1993). Essential and Toxic trace elements in Human Health and Disease. Pp138-146.

[27]. Rink, L. and Gabriel, P. (2000).Zinc and the immune system.Proc.Nutr.Soc. 59:541.

[28]. Shenbagarathai, K. R.,Kavitha, K., Balasubramanian, R. and Ubramanian, P. T. (2008).Serum zinc and albumin levels in pulmonary tuberculosis patients with and without HIV.J. Infect. Dis. 61(3): 202-204.

[29]. Soulth,T.L.,Kim,B.,Hare,D.R.(1990) Zinc fingers and molecular recognition,structure and nucleic acid binding studies of an HIV zinc-like domain.Biochem pharmacol,40:123-129

[30]. Tanaka, Y. Morimoto, I. (1990). Role of zinc in interleukin 2 (IL-2) medicated T-cell activation Scand. J. immunol 31(5).. 547-552.

[31]. Ugwuja, N. and Eze, A.(2006). Comparative Study of Serum Electrolytes, Total Protein, Calcium and Phosphate among Diabetic and HIVIAIDS Patients in Abakaliki, Southeastern, Nigeria. The Internet Journal of Laboratory Medicine, 2(1) 6067s. 